\title{
Response of onion to different nitrogen levels and method of transplanting in moderately salt affected soil
}

\author{
Muhammad Qaisar NAWAZ ${ }^{1}$, Khalil AHMED ${ }^{1}$, Syed Saqlain HUSSAIN ${ }^{1}$, Muhammad RIZWAN $^{1}$, Muhammad \\ SARFRAZ ${ }^{1}$, Ghulam Mustafa WAINSE ${ }^{1}$, Muhammad JAMIL ${ }^{1}$
}

Received November 30, 2016; accepted February 02, 2017.

Delo je prispelo 30. novembra 2016, sprejeto 02. februarja 2017.

\begin{abstract}
Rapid increase in population and consumption, urged upon the agronomists to develop a comprehensive site specific agro technology to boost up production per unit area and quality of daily dietary onion crop in salt affected soils by improving some basic components of the prevailing onion production technology in Pakistan. In this perspective a detailed and systematic series of field studies were undertaken for three consecutive years (2013 - 2015) at Soil Salinity Research Institute, Pindi Bhattian, Pakistan to evaluate different nitrogen levels and the cost-effective planting technique for onion production under salt affected conditions. The experiment was laid out in split plot arrangement using randomized complete block design having three replications. Two planting methods, ridge and bed planting and 4 nitrogen levels, 1- recommended dose (RD) of N $\left(90 \mathrm{~kg} \mathrm{ha}^{-1}\right), 2-75 \%$ $\mathrm{N}$ of RD (67.5 kg ha-1), $3-125 \% \mathrm{~N}$ of RD (112.5 $\left.\mathrm{kg} \mathrm{ha}^{-1}\right), 4$ $150 \% \mathrm{~N}$ of RD (135 kg ha-1) were used. Planting methods were kept in main plots and nitrogen levels in sub plots keeping sub-plot size of $4 \mathrm{~m} \times 6 \mathrm{~m}$. Measurements included were: plant height, number of leaves/plants $/ \mathrm{m}^{-2}$, bulb diameter, bulb mass, total bulb yield, number of flowers/umbel, seed mass/plant and 1000-seed mass. Results showed that maximum onion yield and yield attributes were recorded with nitrogen application at rate of $150 \& 125$ of RD in ridge planting. However nitrogen application at rate of 125 of RD in ridge planting recorded higher economic returns over all the other treatments and is recommended as most cost effective technique for onion production under salt affected soil as compare to other treatments.
\end{abstract}

Key words: onion; nitrogen fertilization; planting technique; salinity; cost benefit

\section{IZVLEČEK}

\section{ODZIV ČEBULE NA RAZLIČNA GNOJENJA Z DUŠIKOM IN TEHNIKE SADNJE V RAZMERAH ZMERNO SLANIH TAL}

Hitra rast prebivalstva in $\mathrm{z}$ njim povezana poraba hrane zahtevata od agronomov, da razvijajo in izbolšujejo primerne, rastiščem prilagojene tehnike pridelave čebule glede na enoto površine in kakovost dnevne porabe $\mathrm{v}$ razmerah slanih tal $\mathrm{v}$ Pakistanu. V treh zaporednih rastnih sezonah (2013 - 2015) so bili opravljeni podrobni in sistematični poljski poskusi na Soil Salinity Research Institute, Pindi Bhattian, Pakistan $\mathrm{z}$ namenom ovrednotenja učinkov različnega gnojenja $\mathrm{Z}$ dušikom in različnih tehnik sadnje čebule $\mathrm{v}$ razmerah slanih tal. Poskus je bil zasnovan na osnovi deljenk kot popoln naključni bločni poskus s tremi ponovitvami. Uporabljena sta bila dva načina sadnje, na grebene in v brazde ter štiri načini gnojenja z dušikom glede na priporočeno dozo (RD, 90): 1 priporočena doza (RD) $\left(90 \mathrm{~kg} \mathrm{ha}^{-1}\right), 2-75 \% \mathrm{~N}$ od RD $\left(67.5 \mathrm{~kg} \mathrm{ha}^{-1}\right), 3-125 \% \mathrm{~N}$ od RD $\left(112.5 \mathrm{~kg} \mathrm{ha}^{-1}\right)$ in $4-150 \%$ $\mathrm{N}$ od RD (135 kg ha $\left.{ }^{-1}\right)$. Obravnavanja $\mathrm{z}$ načini sadnje so bila na glavnih ploskvah, obravnavanja gnojenja $\mathrm{z} N$ pa na podploskvah velikost $4 \mathrm{~m}$ x $6 \mathrm{~m}$. Meritve so obsegale višino rastlin, število listov/rastlino $/ \mathrm{m}^{2}$, premer čebule, maso čebul, celokupni pridelek čebul, število cvetov na kobul, maso semena na rastlino in maso 1000 semen. Rezultati so pokazali največji pridelek čebule in njegovih delov pri obravnavanjih z dušikom 150 in $125 \%$ od priporočene doze (RD) in pri sadnji na grebene. Pri tem je obravnavanje $\mathrm{z}$ dušikom $125 \%$ od priporočene doze in sadnja na grebene dalo največji ekonomski učinek $\mathrm{v}$ primerjavi $\mathrm{z}$ drugimi in ga priporočamo kot stroškovno najbolj učinkovit način pridelave čebule $\mathrm{v}$ razmerah zasoljenih tal.

Ključne besede: čebula; dušikova gnojila; načini sadnje; slanost; analiza stroškov in koristi

\section{INTORODUCTION}

Among vegetables, Allium species have worldwide consumption and emerged as popular dietary items in many countries because of its high nutritive value and specific flavor properties (Griffith et al., 2002). In Pakistan onion crop is grown approximately on 0.153 million hectares with a reported production of 2.015

1 Soil Salinity Research Institute (SSRI), Pindi Bhattian; *corresponding author: khalilahmeduaf@gmail.com 
million tons whereas average yield is $13.2 \mathrm{t}$. ha-1 (GOP, 2015). Across the world, average onion consumption is approximately $6.5 \mathrm{~kg}$ per capita per annum while in Pakistan, it is $10 \mathrm{~kg}$ per annum (Kabir, 2007). Keeping in view the rapid increase in population and consumption level, Pakistan has to produce about 15 million tons of onion per annum. So as to remain selfsufficient in onion, not only the area of production but also productivity per unit area needs to be increased extensively. Rapid increase in population is exerting more pressure on its demand. Hence the farmers can in turn obtain good remuneration by producing this important crop by utilization of marginal lands owing to its increasing demand in local market and exportation commodity. Due to arid to semi-arid climate, Pakistan has $6.67 \mathrm{~m} \mathrm{ha}$ of salt affected land which is approximately $1 / 3 \mathrm{rd}$ of the total cultivated area $($ Khan,1998) and therefore great scope exists to increase production of this cash value crop through strengthening research and development activities in salt affected soils.

Onion is classified as relatively salt sensitive crop with threshold level of $1.2 \mathrm{dSm}-1$ electrical conductivity (EC) (Mass and Hoofman, 1977). Consequently, for better yield and quality of onion in salt affected soil, there is need to improve cultivation methods, like planting method, planting time, proper planting geometry, optimum fertilization and other management practices for farmers to grow onion crops in salt affected soils at a commercial scale.

Nitrogen performs a critical role during photosynthesis and is also an indispensable part of protein. It is vital for many physiological and biochemical reactions of plant metabolism (Balasubramaniyan and Palaniappan, 2001; Epstein and Bloom, 2006). Nitrogen management efficiency assumes greater importance in salt affected soils and have to follow an optimal nitrogen fertilization strategy for sustainable onion production (Songzhong, 2009). Because nitrogen, constitute approximately $80 \%$ of the total mineral nutrients absorbed by plants (Marschner, 1995). Under most agro ecological conditions, nitrogen has been reported as one of the most yield limiting nutrients for crop production and its effective use is imperative for the economic sustainability of cropping systems (Fageria and Baligar, 2005). Considering the benefits of fertilization, some researchers have reported that addition of nitrogen and phosphorus alleviate the harmful effect of salt stress and osmotic stress on plants (Grattan and Grieve, 1999; Kaya and Higgs, 2002; Kaya and Higgs, 2003; AbuRomman and Suwwan, 2012; Abu-Romman et al., 2013). Onion productivity could be increased substantially through use of improved cultivars and optimum use of fertilizers (Shaheen, 2007). Nitrogen application in onion significantly influences the flavor, development and quality of bulb (Randle, 2000). Several researcher have reported higher levels of $\mathrm{N}$ considerably improved the production of onion over low level of nitrogen (Khan et al., 2002; Ghaffoor et al., 2003; Al Abdulsalam and Hamaiel, 2004; Moursy et al., 2007; Yaso et al., 2007; Nemat et al., 2011; Dhital et al., 2015).

Suggested agronomic practices for saline soils comprise irrigation at night to avoid evaporation loss (Rhoades, 1999), better cultivation approaches like sowing on raised beds, pre-sowing seed treatments to improve germination even in salt stress environment (Sayre, 2007; Egamberdiev, 2007; Bakker et al., 2010). Improved planting technique not only help to maintain optimize plant population by avoiding excessive crowding but also allow plants to exploit land, light, and other input resources uniformly and efficiently. Saline soil, owing to its high bulk density and low porosity, confines the plant roots in the upper surface layer and reduces the soil volume which could be explored by the plants for water and nutrients acquisition. In ridges planting plants establish well developed root system due to loose fertile layer of soil with more surface area (Bucher, 2007; Ao et al., 2010; Khan et al., 2012). Bakht et al. (2011) reported that planting methods had significant effect on the yield and yield components of different maize varieties, maximum plant height, number of plants $\mathrm{ha}^{-1}$, more grain and biological yield was recorded in ridge planting. Khan et al. (2000) reported maximum yield of canola in ridge planting method as irrigation next to seed resulted movement of salts away from seed producing less saline environment in ridges. Malik et al. (2001) also reported the maximum yield of sunflower in ridge planting pattern than other conventional planting methods. Keeping above facts, series of experiments were taken with view to understand a cohesive evaluation of onion fertilizer requirements and planting method while meeting specific extension needs of growers in salt affected areas.

\section{MATERIALS AND METHODS}

Field trial was set and carried out for three consecutive winter season from 2013 to 2015 at
Soil Salinity Research Institute Pindi Bhattian. The $\mathrm{pH}$ of saturated soil paste was 8.67 , electrical conductivity of soil extract $\left(\mathrm{EC}_{\mathrm{e}}\right)=4.10(\mathrm{dS} \mathrm{m}-1)$ and sodium 
absorption ratio $(\mathrm{SAR})=34.41\left(\mathrm{mmol} \mathrm{l}^{-1}\right)^{1 / 2}$. The experiment was laid out in split plot arrangement using randomized complete block design having three replications. Two planting methods (ridge planting and raised bed planting) and 4 nitrogen levels 1recommended dose $(\mathrm{RD})$ of $\mathrm{N}\left(90 \mathrm{~kg} \mathrm{ha}^{-1}\right), 2-75 \% \mathrm{~N}$ of RD (67.5 kg ha $\left.{ }^{-1}\right), 3-125 \% \mathrm{~N}$ of RD $\left(112.5 \mathrm{~kg} \mathrm{ha}^{-1}\right)$, $4-150 \% \mathrm{~N}$ of RD (135 $\left.\mathrm{kg} \mathrm{ha}^{-1}\right)$ were used in the study. Planting methods were kept in main plots and nitrogen levels in sub plots keeping sub-plot size of $4 \mathrm{~m} \times 6 \mathrm{~m}$. Bulbs of onion (Allium cepa L.) cultivar namely 'Phulkara' were planted in $3^{\text {rd }}$ week of December for three consecutive years. Fertilizer dose of P, K (90-60 $\mathrm{kg} \mathrm{ha}^{-1}$ ) and nitrogen according to treatment plan was used at the time of land preparation in the form of single super phosphate, sulphate of potash and urea respectively. All the standard agronomic management practices were adopted. The data regarding different agronomic parameters like plant height, number of leaves/plants, bulb diameter, bulb mass, bulb yield, number of flowers/umbel, seed yield/plant and 1000seed mass were recorded and subjected to analysis of variance following the method of Steel et al. (1997) to sort out significant differences among treatments at $5 \%$ probability level using STATISTIX 8.1 package software. In order to assess the economic feasibility of different nitrogen levels and planting methods used, an economic analysis was evaluated (Shah et al., 2013).

\section{RESULTS AND DISCUSSION}

\subsection{Plant height (cm)}

Pooled data of three years regarding plant height evidenced linear response with increasing nitrogen levels, as well as for $\mathrm{N}$ by planting methods interaction (Table 1). Treatment using nitrogen at rate of $150 \%$ of $\mathrm{RD}$ recorded the highest plant height $(56.16 \mathrm{~cm})$ which was followed by $125 \% \mathrm{~N}$ of RD with plant height of $(55.33 \mathrm{~cm})$ however difference between both treatments was not statistically significant $(\mathrm{P} \leq 0.05)$. The lowest plant height $(36.00 \mathrm{~cm})$ was estimated with nitrogen dose at rate of $75 \%$ of RD. Planting method, however, did not influenced the plant height, ridge planting produced greater plant height $(49.16 \mathrm{~cm})$ than bed planting $(46.41 \mathrm{~cm})$ but both treatments were statistically non-significant. Data regarding interactive effect of nitrogen levels and planting method showed that nitrogen at rate of $150 \%$ of RD in ridge planting documented the taller plant of $(57.00 \mathrm{~cm})$ which was statistically similar with $\mathrm{N}$ at rate of $150 \%$ of RD with bed planting and nitrogen application at rate of $125 \%$ of $\mathrm{RD}$ in ridge and bed planting respectively. Nitrogen is one of the most important growth-limiting macro nutrient in salt affected soils (Gupta and Abrol, 1990; Curtin and Naidu, 1998; Irshad et al., 2002) and its availability is also affected in these soils as $\mathrm{NH}_{3}$ volatilized due to high $\mathrm{pH}$ (Gupta and Abrol, 1990) and $\mathrm{NO}_{3}$ uptake is inhibited by $\mathrm{Cl}^{-1}$ which is usually present at toxic concentrations in salt affected soils (Grattan and Grieve, 1999). Salt stressed crop generally needs an additional $25 \%$ more $\mathrm{N}$ than the same cropping sequence used on normal soils for improved plant growth and yield (Gupta and Abrol, 1990). In our study this remarkable increase in plant height with higher level of nitrogen than recommended may be explained by increased vegetative growth probably due to efficient exploitation of absorbed nutrients and improved nourishment through nitrogen application (Bhakher et al., 1997). Ours finding are in consistent with Aregawi (2006) who reported that $\mathrm{N}$ fertilization at $150 \mathrm{~kg} \mathrm{~N} \mathrm{ha}^{-1}$ and $180 \mathrm{~kg} \mathrm{~N} \mathrm{ha}^{-1}$, respectively increased plant height more than in plots that received no $\mathrm{N}$ fertilization. Similarly Subedi (2001) reported the positive effect of different levels of $\mathrm{N}$ on plant height.

\subsection{Number of leaves/plants}

Concerning to number of leaves a pronounced effect was found for N. Results display in Table 1 showed that there was a notable increase $(\mathrm{P} \leq 0.05)$ in number of leaves/plants with increasing levels of nitrogen over $100 \% \mathrm{~N}$ of RD than at lower level of $\mathrm{N}$. With respect to planting techniques, ridge planting proved superior with number of leaves of 8.75 over bed planting with 7.91 number of leaves. Pooled data reflected that maximum number of leaves (10.16) was produced in $150 \% \mathrm{~N}$ of $\mathrm{RD}$ followed by $125 \% \mathrm{~N}$ of $\mathrm{RD}$, however, the differences in level of $\mathrm{N}$ from $125 \%$ to $150 \%$ of RD could not show significant differences on this parameter and minimum number of leaves (6.16) was recorded in $75 \% \mathrm{~N}$ of RD. Interaction between nitrogen levels and planting methods also showed pronounced effect on leaves number. Greater number of leaves (10.66) was recorded in ridge planting, where nitrogen was applied at rate of $150 \%$ of RD however it was statistically nonsignificant with $125 \% \mathrm{~N}$ of RD. Higher number of leaves in ridge planting against bed planting may be explained that ridge planting rendered favorable growth conditions and improved nutrient absorption capacity (Bakht et al., 2011). Similar results are also reported by Siddique and Bakht (2005) and Bakht et al. (2006) that maximum grain yield in maize was recorded in ridge planting. The positive effect of higher dose of nitrogen on leaf length may be attributed to its role in synthesis of proteins, enzymes, chlorophyll, and the occurrence of more protein leads to increase the leaves size and consequently carbohydrate synthesis is accelerated (Bungard et al., 1999). Our results are in accordance with findings of other authors (Neeraja et al., 2001; Diaz-Perez et al., 2003; Singh et al., 2004; Jilani 2004) 
that nitrogen fertilization significantly increases leaves length in onion.

\subsection{Bulb diameter $(\mathrm{cm})$}

A perusal of data regarding the bulb diameter it could be observed that nitrogen levels, planting methods and their interactive effect significantly $(\mathrm{P} \leq 0.05)$ increase bulb diameter (Table 1). Over all mean value of three years showed that the highest bulb diameter $(5.80 \mathrm{~cm})$ was recorded in $150 \% \mathrm{~N}$ of $\mathrm{RD}$ but it was nonsignificant with $125 \% \mathrm{~N}$ of RD and the minimum bulb diameter was found in $75 \% \mathrm{~N}$ of RD obtaining value of $4.42 \mathrm{~cm}$. In respect to the planting methods, onion planted on ridges produced the maximum bulb diameter of $(5.29 \mathrm{~cm})$ when compared with bed planting method $(5.12 \mathrm{~cm})$. Planting methods and nitrogen interaction was also found significant. Nitrogen at rate of $150 \%$ of $\mathrm{RD}$ with ridge planting produced bulb diameter of 5.85 followed by $125 \% \mathrm{~N}$ of $\mathrm{RD}$ in ridge planting however statistically no difference was found among two fertilizer levels in ridge and bed planting. In salt affected field, reduction in root-zone salinity is one of effective approach to enhance crop emergence and stand establishment (Dong et al., 2008). Raised beds offered a large surface area than ridges and under saline conditions, salt accumulation on top of the beds increased due to upward movement of groundwater driven by evaporation (Deng et al., 2003; Qiao et al., 2006 and Bakker et al., 2010). Comparable findings are also stated by (Arif et al., 2001; Oswald et al., 2002; Rasheed et al., 2003) that in maize, ridge planting gave better results than other sowing methods. Results of present study coincide with the reports of many researchers that bulb length increase markedly in response to nitrogen application (Hussaini et al., 2000; Mandira and Khan, 2003; Lee et al., 2003; Yadav et al., 2003; Reddy et al., 2005; Nasreen et al., 2007).

\subsection{Bulb mass (g)}

As far as bulb mass is concerned pooled data of three consecutive seasons, showed pronounced effect of successive increasing levels of nitrogen on bulb mass and interaction of $\mathrm{N} x$ planting methods (Table 1). Treatment using nitrogen at rate of $150 \%$ of RD for which the peak value of bulb mass (59.25 g) was recorded against $\mathrm{N}$ at rate of $125 \%$ of $\mathrm{RD}$ with bulb mass of $(58.78 \mathrm{~g})$ however difference between these two treatments was not large enough to reach the level of significance. Results reflected that ridge planting produced significantly higher bulb mass of (53.86 g) than bed planting (50.94 g). Data regarding interactive effect of nitrogen levels and planting methods showed that nitrogen at rate of $150 \%$ of RD with ridge planting produce maximum bulb mass (60.93 g) which was statistically alike with nitrogen at rate of $125 \%$ of RD with ridge planting followed by nitrogen at rate of 150
\& $125 \%$ of RD with bed planting. Optimum fertilization in salt affected soil resulted in better crop yields by improving nutrient contents in plant tissue and soil solution (Adediran et al., 2004) and may produce $67 \%$ of additional yield than normal field (Taiwo et al., 2001). So optimum level of nitrogen that precisely match crop requirements lessens the chances for $\mathrm{N}$ loss as the plant is established and rapidly taking it up (Andraski et al., 2000). The increase in bulb mass with application of $\mathrm{N}$ at rate of $125 \& 150 \%$ of RD could be ascribed to overall improvement in crop growth and vigor, due to more root proliferation, improved nutrients and water uptake, greater leaf number, more photosynthesis and accelerated rate of assimilation (Yadav et al., 2005). These results show responsiveness of the onion to nitrogen fertilization and support the earlier findings of many authors that the nitrogen contributes markedly to production of larger bulbs. (Baghour et al., 2001; Anwar et al., 2001; Ghaffoor et al., 2003; Lee et al., 2003; Mandira and Khan, 2003; Arian et al., 2004; Gautam and Pande, 2005). Moreover in ridge planting fertile soil is more loose with improved aeration and moisture supply and low resistance to new emerging roots for exploitation of more surface area for nutrient acquisition might be the reason of better growth in ridge sown maize crop (Chassot and Richner, 2002).

\subsection{Bulb yield $\left(\mathrm{t} \mathrm{ha}^{-1}\right)$}

Bulb yield depicted in (Table 2) revealed significant difference among the planting methods and different nitrogen levels and interaction of nitrogen and planting methods. $\mathrm{N}$ at rate of $125 \& 150 \%$ of RD were most effective treatments in increasing bulb yield, 19.65 and $19.61 \mathrm{t} \mathrm{ha}^{-1}$ respectively however statistically both treatments were alike and the lowest value of bulb yield (15.60 $\left.\mathrm{t} \mathrm{ha}^{-1}\right)$ was noted where nitrogen was applied at rate of $75 \%$ of $\mathrm{RD}$. With respect to the planting methods, ridge planting has better effect on bulb yield (18.29 $\left.\mathrm{t} \mathrm{ha}^{-1}\right)$ as compared to bed planting (18.01 $\left.\mathrm{t} \mathrm{ha}^{-1}\right)$. Interaction of nitrogen levels and planting methods showed that the greater bulb yield $\left(19.71 \mathrm{t} \mathrm{ha}^{-1}\right)$ was produced with nitrogen at rate of $150 \%$ of RD with ridge planting and statistically was similar to nitrogen at rate of $125 \%$ of $\mathrm{RD}$ in bed planting and the minimum bulb yield $\left(15.38 \mathrm{t} \mathrm{ha}^{-1}\right)$ was achieved in $75 \% \mathrm{~N}$ of RD with bed planting. Arid to semi-arid climate of Pakistan results in very low soil organic matter hence availability of nitrogen for optimum plant growth and development is very low and this situation becomes worse in salt affected soil due to excess of $\mathrm{Cl}^{-1}$ which antagonizes the uptake of nitrogen (Grattan and Grieve, 1999). The increased in bulb yield with increasing levels of nitrogen can be justified by the fact that nitrogen performs a critical role during photosynthesis and is also an indispensable part of protein. It is vital for many physiological and biochemical reactions of plant 
metabolism (Balasubramaniyan and Palaniappan, 2001; Epstein and Bloom, 2006) and ultimately yield is improved. The current results of this study are in strong agreement with findings of different authors who reported the stimulatory effect of nitrogen on onion yield (Ehsan et al., 2002 ; Cizauskas et al., 2003; Abdissa et al., 2011). Our results also confirmed the findings of Choudhary et al., (2008) that in salt affected field, salt accumulation increases on top of the beds, and bigger bulb yield in ridge planting might also be due to the more favorable soil conditions created by ridges. That result in better roots development allowing the plants to uptake more nutrients and moisture (Rasheed et al., 2004; Amin et al., 2006; Abdullah et al., 2007; Ghaffar et al., 2012). Similar results have been also reported by Liu and Yong (2008) and Belachew and Abera (2010).

\subsection{Number of flower/umbel}

As seems to be appearent from data, the Table 2 revealed that the additional response of nitrogen fertilization and planting method on number of flowers was statistically $(P \leq 0.05)$ significant. $150 \% \mathrm{~N}$ of $\mathrm{RD}$ produced maximum number of flowers (150.33) which was statistically alike with $125 \% \mathrm{~N}$ of $\mathrm{RD}$ and consequently reduced number of flowers were evidenced in $75 \% \mathrm{~N}$ of RD having flowers of (134.83) followed by $\mathrm{N}$ at rate of $\mathrm{RD}$. In the case of planting methods the maximum number of flowers (146.17) was noted in ridge planting which differed significantly from bed planting with 142.83 of flowers/umbel. Interaction between nitrogen levels and planting methods showed that $\mathrm{N}$ at rate of $150 \%$ of $\mathrm{RD}$ with ridge planting recorded the highest number of flowers (151.67) however statistically no significant difference was found among $\mathrm{N}$ at rate of $125 \%$ of $\mathrm{RD}$ in ridge planting and $\mathrm{N}$ at rate of $150 \%$ of RD in bed planting. Being shallow rooted crop, onion is highly responsive to nitrogen application at high rate which markedly improved the production. More surface area from bare top soils of bed results more evaporation rates which leads to more salt accumulation as compared to ridge. (Choudhary et al., 2008; Cardon et al., 2010). Our results coincide with findings of Liu \& Young (2008) and Belachew and Abera (2010).

\subsection{Seed yield/plant (g)}

The results presented in Table 2 revealed that the effect of nitrogen fertilization and planting methods on seed yield/plant was statistically $(\mathrm{P} \leq 0.05)$ significant. $150 \% \mathrm{~N}$ of $\mathrm{RD}$ produced the maximum seed yield $(1.29 \mathrm{~g})$ which was of slightly higher value than found in $125 \% \mathrm{~N}$ of $\mathrm{RD}$, so statistically both the treatments were similar and minimum seed yield was recorded in $75 \% \mathrm{~N}$ of RD with seed yield of $(0.73 \mathrm{~g})$. In case of planting methods the maximum seed yield $(1.11 \mathrm{~g})$ was noted in ridge planting which differed significantly from bed planting with $1.03 \mathrm{~g}$ seed yield/plant. Interactive effect of nitrogen levels and planting methods showed that $\mathrm{N}$ at rate of $150 \%$ of $\mathrm{RD}$ with ridge planting recorded the highest value of seed yield $(1.32 \mathrm{~g})$ however statistically no significant difference was found among $\mathrm{N}$ at rate of $150 \%$ of RD in bed planting and $\mathrm{N}$ at rate of $125 \%$ of $\mathrm{RD}$ in ridge and bed planting respectively. By analyzing results obtained from three consecutive seasons it could be concluded that $\mathrm{N}$ at rate of $125 \%$ of $\mathrm{RD}$ is the dose which gave the best response in interaction with ridge planting. These findings are confirmed also by those, reported by Ali et al. (2007) that $\mathrm{N}$ dose up to $150 \mathrm{~kg} \mathrm{ha}^{-1}$ in onion produced bigger number of flowers, better fruit set and seed yield significantly. Current findings corroborate the report of Bakht et al. (2011) who suggested that ridge planting rendered better growth conditions and improved nutrient absorption capacity.

\section{$3.8 \quad 1000$-seeds mass $(\mathrm{g})$}

The results presented in Table 2 depicted that the maximum 1000-seeds mass occurred by applying nitrogen level of $125 \& 150 \%$ of RD. Treatment where $\mathrm{N}$ was applied at rate of $150 \%$ of RD produced the maximum seed yield $(2.37 \mathrm{~g})$ which was statistically alike with $125 \% \mathrm{~N}$ of RD and the minimum 1000-seed mass of ( $1.98 \mathrm{~g})$ was noted at the dose of $75 \% \mathrm{~N}$ of RD. In case of planting methods the maximum 1000-seed mass $(2.24 \mathrm{~g})$ was noted in ridge planting which differed significantly from bed planting with $2.14 \mathrm{~g}$ seed mass. Nitrogen levels and planting methods interaction showed that $\mathrm{N}$ at rate of $150 \%$ of $\mathrm{RD}$ with ridge planting recorded the highest value of 1000-seed mass $(2.40 \mathrm{~g})$ however statistically no significant difference was found among $\mathrm{N}$ at rate of $150 \%$ of $\mathrm{RD}$ in bed planting and $\mathrm{N}$ at rate of $125 \%$ of RD in ridge and bed planting respectively. These results are in agreement with previous findings which showed the positive responses of $\mathrm{N}$ application on onion crops (Neeraja et al., 2001; Diaz-Perez et al., 2003; Singh et al., 2004).

\subsection{Economic analysis}

Economic feasibility in financial terms of any innovation or technique has primary importance in deciding its wider adoption among farming community (Khan et al., 2012). Economic analysis was carried out at the end of study to evaluate the best and economical nitrogen level and planting technique to grow onion crop under salt affected conditions. Different planting technique and nitrogen levels resulted in different net income as indicated in the Table 3. Data regarding economic analysis for different treatments revealed that the highest net income (Rs. $300800 \mathrm{ha}^{-1}$ ) with cost benefit ratio of (4.34) was earned with nitrogen application at rate of $125 \%$ of $\mathrm{RD}$ in ridge planting as 
compare to other treatments which may be due to more economic yield.

\section{CONCLUSION}

In salt affected field among the agronomic practices, planting methods are of substantial importance as proper adjustment of plants in such field not only ensures optimum plant population but also allows the plants to exploit the soil and other external resources more expeditiously and judicially towards growth and higher yield production. Findings of the present studies suggested the level of $\mathrm{N}$ at rate of $125 \%$ of $\mathrm{RD}$ as a way to unify with ridge planting method that would promote the highest yield of onion crop under salt affected soils.

Table 1: Different parameters of onion as affected by different nitrogen rates and planting methods under saline conditions

\begin{tabular}{|c|c|c|c|}
\hline Treatments & Ridge Planting & Bed Planting & Mean \\
\hline \multicolumn{4}{|l|}{ Plant height (cm) } \\
\hline Recommended dose (RD) & $45.66 \mathrm{~b}$ & $41.66 \mathrm{c}$ & $43.66 \mathrm{~b}$ \\
\hline $75 \% \mathrm{~N}$ of RD & $37.66 \mathrm{~d}$ & $34.33 \mathrm{~d}$ & $36.00 \mathrm{c}$ \\
\hline $125 \% \mathrm{~N}$ of $\mathrm{RD}$ & $56.33 \mathrm{a}$ & $54.33 \mathrm{a}$ & $55.33 \mathrm{a}$ \\
\hline $150 \% \mathrm{~N}$ of $\mathrm{RD}$ & $57.00 \mathrm{a}$ & $55.33 \mathrm{a}$ & $56.16 \mathrm{a}$ \\
\hline Mean & $49.16 \mathrm{a}$ & $46.41 \mathrm{a}$ & \\
\hline \multicolumn{4}{|l|}{ Number of leaves/plant } \\
\hline Recommended dose (RD) & $7.66 \mathrm{~d}$ & $6.66 \mathrm{e}$ & $7.16 \mathrm{~b}$ \\
\hline $75 \% \mathrm{~N}$ of $\mathrm{RD}$ & $6.33 \mathrm{e}$ & $6.00 \mathrm{e}$ & $6.16 \mathrm{c}$ \\
\hline $125 \% \mathrm{~N}$ of $\mathrm{RD}$ & $10.33 \mathrm{ab}$ & $9.33 \mathrm{c}$ & $9.83 \mathrm{a}$ \\
\hline $150 \% \mathrm{~N}$ of $\mathrm{RD}$ & $10.66 \mathrm{a}$ & $9.66 \mathrm{bc}$ & $10.16 \mathrm{a}$ \\
\hline Mean & $8.75 \mathrm{a}$ & $7.91 \mathrm{~b}$ & \\
\hline \multicolumn{4}{|l|}{ Bulb diameter (cm) } \\
\hline Recommended dose (RD) & $5.02 \mathrm{~b}$ & $4.66 \mathrm{c}$ & $4.84 \mathrm{~b}$ \\
\hline $75 \% \mathrm{~N}$ of $\mathrm{RD}$ & $4.48 \mathrm{~cd}$ & $4.36 \mathrm{~d}$ & $4.42 \mathrm{c}$ \\
\hline $125 \% \mathrm{~N}$ of $\mathrm{RD}$ & $5.81 \mathrm{a}$ & $5.73 \mathrm{a}$ & $5.77 \mathrm{a}$ \\
\hline $150 \% \mathrm{~N}$ of $\mathrm{RD}$ & $5.85 \mathrm{a}$ & $5.75 \mathrm{a}$ & $5.80 \mathrm{a}$ \\
\hline Mean & $5.29 \mathrm{a}$ & $5.12 \mathrm{~b}$ & \\
\hline \multicolumn{4}{|l|}{ Bulb mass (g) } \\
\hline Recommended dose (RD) & $49.33 \mathrm{c}$ & $47.10 \mathrm{c}$ & $48.21 \mathrm{~b}$ \\
\hline $75 \% \mathrm{~N}$ of $\mathrm{RD}$ & $44.73 \mathrm{~d}$ & $42.00 \mathrm{e}$ & $43.36 \mathrm{c}$ \\
\hline $125 \% \mathrm{~N}$ of $\mathrm{RD}$ & $60.46 \mathrm{a}$ & $57.10 \mathrm{~b}$ & $58.78 \mathrm{a}$ \\
\hline $150 \% \mathrm{~N}$ of $\mathrm{RD}$ & $60.93 \mathrm{a}$ & $57.56 \mathrm{~b}$ & $59.25 \mathrm{a}$ \\
\hline Mean & $53.86 \mathrm{a}$ & $50.94 \mathrm{~b}$ & \\
\hline
\end{tabular}

Means sharing the same small letters are statistically similar by LSD at $\mathrm{P} \leq 0.05$ 
Table 2: Different parameters of onion as affected by different nitrogen rates and planting methods under saline conditions

\begin{tabular}{|c|c|c|c|}
\hline Treatments & Ridge Planting & Bed Planting & Mean \\
\hline \multicolumn{4}{|l|}{ Bulb yield $\left(t\right.$ ha $\left.^{-1}\right)$} \\
\hline Recommended dose (RD) & $17.93 \mathrm{~b}$ & $17.54 \mathrm{c}$ & $17.73 \mathrm{~b}$ \\
\hline $75 \% \mathrm{~N}$ of RD & $15.83 \mathrm{~d}$ & $15.38 \mathrm{e}$ & $15.60 \mathrm{c}$ \\
\hline $125 \% \mathrm{~N}$ of RD & $19.68 \mathrm{a}$ & $19.54 \mathrm{a}$ & $19.61 \mathrm{a}$ \\
\hline $150 \% \mathrm{~N}$ of $\mathrm{RD}$ & $19.71 \mathrm{a}$ & $19.60 \mathrm{a}$ & $19.65 \mathrm{a}$ \\
\hline Mean & $18.29 \mathrm{a}$ & $18.01 \mathrm{~b}$ & \\
\hline \multicolumn{4}{|l|}{ Number of flowers/umbel } \\
\hline Recommended dose (RD) & $145.00 \mathrm{c}$ & $141.67 \mathrm{~d}$ & $143.33 \mathrm{~b}$ \\
\hline $75 \% \mathrm{~N}$ of $\mathrm{RD}$ & $137.33 \mathrm{e}$ & $132.33 \mathrm{f}$ & $134.83 \mathrm{c}$ \\
\hline $125 \% \mathrm{~N}$ of $\mathrm{RD}$ & $150.67 \mathrm{ab}$ & $148.33 \mathrm{~b}$ & $149.50 \mathrm{a}$ \\
\hline $150 \% \mathrm{~N}$ of $\mathrm{RD}$ & $151.67 \mathrm{a}$ & $149.00 \mathrm{ab}$ & $150.33 \mathrm{a}$ \\
\hline Mean & $146.17 \mathrm{a}$ & $142.83 \mathrm{~b}$ & \\
\hline \multicolumn{4}{|l|}{ Number of seeds/plant } \\
\hline Recommended dose (RD) & $1.06 \mathrm{~b}$ & $0.92 \mathrm{c}$ & $0.99 \mathrm{~b}$ \\
\hline $75 \% \mathrm{~N}$ of $\mathrm{RD}$ & $0.76 \mathrm{~d}$ & $0.71 \mathrm{~d}$ & $0.73 \mathrm{c}$ \\
\hline $125 \% \mathrm{~N}$ of $\mathrm{RD}$ & $1.29 \mathrm{a}$ & $1.25 \mathrm{a}$ & $1.27 \mathrm{a}$ \\
\hline $150 \% \mathrm{~N}$ of $\mathrm{RD}$ & $1.32 \mathrm{a}$ & $1.27 \mathrm{a}$ & $1.29 \mathrm{a}$ \\
\hline Mean & $1.11 \mathrm{a}$ & $1.03 \mathrm{~b}$ & \\
\hline \multicolumn{4}{|l|}{ 1000-seeds mass (g) } \\
\hline Recommended dose (RD) & $2.12 \mathrm{~b}$ & $1.98 \mathrm{~cd}$ & $2.05 \mathrm{~b}$ \\
\hline $75 \% \mathrm{~N}$ of $\mathrm{RD}$ & $2.05 \mathrm{bc}$ & $1.92 \mathrm{~d}$ & $1.98 \mathrm{~b}$ \\
\hline $125 \% \mathrm{~N}$ of $\mathrm{RD}$ & $2.39 \mathrm{a}$ & $2.32 \mathrm{a}$ & $2.35 \mathrm{a}$ \\
\hline $150 \% \mathrm{~N}$ of $\mathrm{RD}$ & $2.40 \mathrm{a}$ & $2.34 \mathrm{a}$ & $2.37 \mathrm{a}$ \\
\hline Mean & $2.24 \mathrm{a}$ & $2.14 \mathrm{~b}$ & \\
\hline
\end{tabular}

Means sharing the same small letters are statistically similar by LSD at $\mathrm{P} \leq 0.05$

Table 3: Effect of different nitrogen rates and planting methods on net income and benefit: cost ratio (BCR) of onion crop

\begin{tabular}{|l|l|l|l|l|l|l|l|c|}
\hline \multirow{2}{*}{ Nitrogen levels } & \multicolumn{9}{|c|}{ Planting methods } \\
\cline { 2 - 9 } & \multicolumn{7}{|l|}{ Ridge Planting } & \multicolumn{2}{l|}{ Bed Planting } \\
\cline { 2 - 9 } & $\begin{array}{l}\text { Cost of } \\
\text { production } \\
\text { (Rs.) }\end{array}$ & $\begin{array}{l}\text { Gross } \\
\text { income } \\
\text { (Rs.) }\end{array}$ & $\begin{array}{l}\text { Net } \\
\text { income } \\
\text { (Rs.) }\end{array}$ & $\begin{array}{l}\text { Benefit: } \\
\text { Cost }\end{array}$ & $\begin{array}{l}\text { Cost of } \\
\text { production } \\
\text { (Rs.) }\end{array}$ & $\begin{array}{l}\text { Gross } \\
\text { income } \\
\text { (Rs.) }\end{array}$ & $\begin{array}{l}\text { Net } \\
\text { income } \\
\text { (Rs.) }\end{array}$ & $\begin{array}{l}\text { Benefit: } \\
\text { Cost }\end{array}$ \\
\hline Recommended dose (RD) & 85000 & 358600 & 273600 & 4.218824 & 85000 & 350800 & 265800 & 4.12 \\
\hline $75 \%$ N of RD & 75000 & 316600 & 241600 & 4.221333 & 75000 & 307600 & 232600 & 4.10 \\
\hline $125 \%$ N of RD & 90000 & 393600 & 303600 & 4.373333 & 90000 & 390800 & 300800 & 4.34 \\
\hline $150 \%$ N of RD & 92000 & 394200 & 302200 & 4.284783 & 92000 & 392000 & 300000 & 4.26 \\
\hline
\end{tabular}




\section{REFERENCES}

Abdissa, Y., Tekalign, T., Pant. L.M. (2011). Growth, bulb yield and quality of onion (Allium cepa L.) as influenced by nitrogen and phosphorus fertilization on vertisol I. growth attributes, biomass production and bulb yield. African Journal of Agricultural Research, 6, (14), 3252-3258.

Abdullah, G., Hassan, M., Ahmad, I., Munir, M. (2007). Effect of planting method and herbicides on yield and yield components of maize. Pakistan Journal of Weed Science Research, 13, 39-48.

Abu-Romman, S., Suwwan, M. (2012). Effect of phosphorus on osmotic-stress responses of cucumber microshoots. Advances in Environmental Biology, 6, (5), 1626-1632.

Abu-Romman, S., Suwwan, M., Al-Ramamneh, E. (2013). Alleviation of salt stress by phosphorus in cucumber microshoots grown on rooting medium. World Applied Sciences Journal, 22, (2), 186-191.

Adediran. (2004). Application of organic and inorganic fertilizer for sustainable maize and cowpea yields in Nigeria. Journal of Plant Nutrition, 27, (7), 11631181.

AL Abdulsalam, M.A., Hamaiel, A.F. (2004). Effect of Planting Dates and Compouned Fertilizers on Growth, Yield and Quality of Hassawi Onion Under Al-Hassa Oasis Conditions. Basic and Applied Sciences, 5, (1), 65-79.

Ali, M.K., Alam, M.F., Alam, M.N., Islam, M.S., Khandaker, S.M.A.T. (2007). Effect of Nitrogen and Potassium Level on Yield and Quality Seed Production of Onion. Journal of Applied Sciences Research, 3, (12), 1889-1899.

Amin, M., Razzaq, A., Ramzan, M. (2006). Effect of planting methods, seed density and nitrogen phosphorus fertilizer levels on sweet corn. Journal of Research, (17), 83-89.

Andraski, T.W., Bundy, L.G., Brye, K.R. (2000). Crop management and corn nitrogen rate effects on nitrate leaching. Journal of Environmental Quality, 29 , 1095-1103. doi:10.2134/jeq2000.00472425002900040009x

Anwar, M. N., Sarker, J. U., Rahman, M., Islam, M.A., Begum, M. (2001). Response of onion to nitrogen, phosphorus, potassium, sulphur and zinc. Bangladesh J. Environ. Sci. 7, 68-72.

Ao, J., Fu, J., Tian, J., Yan, X., Liao, H. (2010). Genetic variability for root morph-architecture traits and root growth dynamics as related to phosphorus efficiency in soybean. Functional Plant Biology, 37, 304-312. doi:10.1071/FP09215
Aregawi, T. (2006). Effect of nitrogen and phosphorous on yield and dry matter accumulation of garlic (Allium stivium L.) at Bule woreda, southern Ethiopia. M.Sc. Thesis, Hawassa University, Awassa, Ethiopia.

Arian, A.L., Khushk, A.M., Bloch, A.F., Naseer, A. (2004). Growth and yielding behaviour of onion in response to essential nutrients. Pakistan Journal of Agricultural Research 18, (1), 51-54.

Arif, M., Ullah, I., Khan, S., Ghani, F., Yousafzai, H.K. (2001). Response of maize varieties to different planting methods. Sarhad Journal of Agriculture, 17, 159-163.

Baghour, M., Sanchez, E., Ruiz, J.M., Romero, L. (2001). Metabolism and efficiency of phosphorus utilization during senescence in pepper plants: Response to Nitrogenous and Potassium fertilization. Journal of Plant Nutrition, 24, (11), 1731-1743. doi:10.1081/PLN-100107309

Bakht, J., Shafi, M., Rehman, H., Uddin, R., Anwar, S. (2011). Effect of planting methods on growth, phenology and yield of maize varieties. Pakistan Journal of Botany, 43, (3), 1629-1633.

Bakht, J., Ahmad, S., Tariq, M., Akbar, H., Shafi, M. (2006). Response of maize to planting methods and fertilizer nitrogen. Journal of Agriculture and Biological Science, 1, 8-14.

Bakker, D., Hamilton, M., Hetherington, G.J., Spann, R. (2010). Salinity dynamics and the potential for improvement of water logged and saline land in a Mediterranean climate using permanent raised beds. Soil Tillage Res. 110, (1), 8-24. doi:10.1016/j.still.2010.06.004

Balasubramaniyan, P., Palaniappan, S.P. (2001). Nutrient management. In: Principles and practices of agronomy. Agrobios, India. P,185-188.

Belachew, T., Abera, Y. (2010). Response of maize (Zea mays L.) to tied ridges and planting methods at Goro, Southeastern Ethiopia. American Euroasian Journal of Agronomy, 3, 21-24.

Bhakher, J.R., Sharma, O.P., Jat, B.C. (1997). Effect of nitrogen and farmyard manure on yield and yield attributes of barley (Hordeum vulgare) in a loamy sand soil. Annals of Agricultural Research, 18, 2445.

Bucher, M. (2007). Functional biology of plant phosphate uptake at root and mycorrhiza interfaces. New Phytologist, 173, 11-26. doi:10.1111/j.14698137.2006.01935.x 
Bungard, R.A., Wingler, A., Morton, J.D., Andrews, M. (1999). Ammonium can stimulate nitrate and nitrite reductase in the absence of nitrate in Clematis vitalba. Plant Cell Environment, 22, 859-866. doi:10.1046/j.1365-3040.1999.00456.x

Cardon, G.E., Davis, J.G., Bauder, T.A., Waskom R.M. (2010). Managing Saline soils. http://www.ext.colostate.edu/pubs/crops/00503.htm

Chassot A., Richner, W. (2002). Root characteristics and phosphorus uptake of maize seedlings in a bilayered soil. Agronomy Journal, 94, 118-127. doi:10.2134/agronj2002.0118

Choudhary, M.R., Munir, A., Mahmood, S. (2008). Field soil salinity distribution under furrow-bed and furrow-ridge during wheat production in irrigated environment. Pakistan Journal of Water Research, 12, (2), 33-40.

Cizauskas, A, Viskelis, P., Dris, R., Oladele, O.I. (2003). Influence of nitrogen rates on onion yield, quality and storability. Moor Journal of Agricultural Research, 4, (1), 85-89.

Curtin, D., Naidu, R. (1998). Fertility constraints to plant production. In Sodic Soil: Distribution, Management and Environmental Consequences, Sumner ME, Naidu R (eds). Oxford University Press: NY; 107-123.

Deng, L., Chen, M., Liu, Z., Shen, Q., Wang, H., Wang, J. (2003). Effects of different ground covers on soil physical properties and crop growth on salinealkaline soil. Chinese Journal of Soil Science, 34, (2), 93-97.

Dhital, M., Shakya, S.M., Sharma, M.D., Dutta, J.P. (2015). Effect of Different Levels of Nitrogen on Commercial Onion Varieties for off Season Green Production in Western Chitwan, Nepal. International Journal of Research 2, (3), 268-273.

Diaz-Perez, J.C., Purvis, A.C., Paulk, J.T. (2003). Bolting, yield, and bulb decay of sweet onion as affected by nitrogen fertilization. Journal American Society Horticultural Science, 128, 144-149.

Dong, H.Z., Li, W.J., Tang, W., Zhang, D.M. (2008). Furrow seeding with plastic mulching increase stand establishment and lint yield of cotton in a saline field. Agronomy Journal, 100, 1640-1646. doi:10.2134/agronj2008.0074

Egamberdiev, O. (2007). Dynamics of irrigated alluvial meadow soil properties under the influence of resource saving and soil protective technologies in the Khorezm region. Dissertation. National University of Uzbekistan. 123.

Ehsan, M. A., Bashir, K., Khan, M.Z., Khokhar, K. M. (2002). Effect of potash application on yield of different varieties of onion (Allium cepa L.). Asian Journal of Plant Sciince, 4, (1), 324-325.

Epstein, E., Bloom, A.J. (2006). Nutrição mineral de plantas: princípios e perspectivas. $2^{\text {nd }}$ ed. Londrina, Planta, P, 403.

Fageria, N.K., Baligar, V.C. (2005). Enhancing nitrogen use efficiency in crop plants. Advances in Agromy, 8, 97-185. doi:10.1016/S0065-2113(05)88004-6

Gautam, I. P., Pande, N.C. (2005). Effect of nitrogen and boron on growth and yield of kharif onion (Allium cepa L.) Cv N-53. Nepalese Horticulture, Nepal Horticulture Society, 5, (1), 56.

Ghaffar, A., Ehsanullah, N. Akbar, S.H., Khan, K., Jabran, R.Q., Hashmi, A., Iqbal, Ali. M.A. (2012). Effect of trench spacing and micronutrients on growth and yield of sugarcane (Saccharum officinarum L.). Australian Journal of Crop Science, 6, 1-9.

Ghaffoor, A, Jilani, M.S., Khaliq, G., Waseem, K. (2003). Effect of different NPK levels on the yield of three onion (Allium cepa L.) varieties. Asian Journal Plant Sciences, 2, 342-346. doi:10.3923/ajps.2003.342.346

Government of Pakistan. (2015). Agriculture Statistics of Pakistan, Ministry of food and agriculture Islamabad.

Grattan, S.R., Grieve, C.M. (1999). Salinity mineral nutrient relations in horticultural crops. Scientia Horticulturae, 78, 127-157. doi:10.1016/S03044238(98)00192-7

Griffith, G., Trueman L., Crowter, T., Thomas, B., Smith, B. (2002). Onions - a global benefit to health. Phytother. Res. 16, 603-615. doi:10.1002/ptr.1222

Gupta, R.K., Abrol, I.P. (1990). Salt-affected soils: their reclamation and management for crop production. Advances in Soil Science, 11, 223-288. doi:10.1007/978-1-4612-3322-0_7

Hussaini, M.A., Amans, E.B., Ramalan, A.A. (2000). Yield, bulb size distribution, and storability of onion (Allium cepa L.) under different levels of $\mathrm{N}$ fertilization and irrigation regime. Tropical Agriculture, 77, 145-149.

Irshad, M., Yamamoto, S., Endo, A.E.T., Honna, T. (2002). Urea and manure effect on growth and mineral contents of maize under saline conditions. Journal of Plant Nutrition, 25, 189-200. doi:10.1081/PLN-100108790

Jilani, M.S. (2004). Studies on the management strategies for bulb \& seed production of different

Acta agriculturae Slovenica, 109 - 2, september 2017 
cultivars of onion (Allium cepa L.). $\mathrm{PhD}$ thesis, Gomal University, Dera Ismail Khan.

Kabir, A. (2007). Rising onion prices. Dawn Internet edition. Jan, 01 2007. htm. http.// DAWN.com.

Kaya, C., Higgs, D. (2002). Calcium nitrate as a remedy for salt-stressed cucumber plants. Journal of Plant Nutrition, $\quad 25, \quad 861-871 . \quad$ doi:10.1081/PLN120002965

Kaya, C., Higgs, D. (2003). Relationship between water use and urea application in salt-stressed pepper plants. Journal of Plant Nutrition, 26, 19-30. doi:10.1081/PLN-120016495

Khan, G.S. (1998). Soil salinity/sodicity status in Pakistan, p, 39, Soil Survey of Pakistan, Lahore.

Khan, H., Iqbal, M., Ghaffoor, A., Waseem, K. (2002). Effect of various plant spacing and different Nitrogen levels on the growth and yield of onion. Online Journal of Biological Science, 2, 545-7. doi:10.3923/jbs.2002.545.547

Khan, M.B., Rafiq, R., Hussain, M., Farooq, M. Jabran, K. (2012). Ridge sowing improves root system, phosphorus uptake, growth and yield of maize (zea mays L.) hybrids. The Journal of Animal \& Plant Sciences, 22, (2), 309-317.

Khan, M.J., Khattak, R.A. Khan, M.A. (2000). Influence of sowing method on productivity of canola grown in saline field. Pakistan Journal of Biological Sciences, 3, (4), 687-691. doi:10.3923/pjbs.2000.687.691

Lee, J.T., Ha, I.J., Lee, C.J., Moon, J.S., Cho, Y.C. (2003). Effect of N, P2O5, and K2O application rates and top dressing time on growth and yield of onion (Allium cepa L.) under spring culture in low land. Korean Journal Horticultural Science and Technology, 21, 260-266.

Liu, M.X., Yong, Q.G. (2008). Effects of ridge-furrow tillage on soil water and crop yield in semiarid region. The 2nd International Conference on 16-18 May, 2008. doi:10.1109/icbbe.2008.395

Malik, M.A, Shah, S.H., Mahmood, S., Cheema, M.A. (2001). Effect of Various Planting Geometries on the Growth, Seed Yield and Oil Content of New Sunflower Hybrid (SF-187). International Journal of Agriculture and Biology, 3, (1), 55-56.

Mandira, C., Khan, A.H. (2003). Effect of nitrogen and potassium on growth, yield and yield attributes of onion. New Agriculturist, 14, 09-11.

Marschner, H. (1995). Mineral nutrition of higher plants, $2^{\text {nd }} E d$. Academic press. San Diego.
Mass, E.V., Hoffman G.J. (1977). Crop salt tolerance current assessment. Journal of Irrigation and Drainage Engineering American Society of Civil Engineers. 103, 115-134.

Moursy, M.E., Khalifa, H.E., Attia, M.M., Sayed, M.A., Osman, A.M. (2007). Effect of organic and nitrogen fertilizers and plant densities on onion production in sandy soil under drip irrigation system. Alexandria Journal of Agricultural Research, 55, (1), 103-108.

Nasreen, S., Haque, M.M., Hossain, M.A., Farid, A.T.M. (2007). Nutrient uptake and yield of onion as influenced by nitrogen and sulphur fertilization. Bangladesh Journal of Agricultural Research, 32, (3), 413-420.

Neeraja, G., Reddy, K.M., Reddy, M.S. (2001). Influence of irrigation and nitrogen levels on bulb yield, nutrient uptake and nitrogen use efficiencies in rabi onion (Allium cepa L.). Indian Journal Agricultural Sciences, 7, 109-111.

Nemat, M.A., A.A., Kader, A.E., Attia, M., Alva, A.K. (2011). Effects of Nitrogen Fertilization and Soil Inoculation of Sulfur-Oxidizing or Nitrogen-Fixing Bacteria on Onion Plant Growth and Yield. International Journal of Agronomy, 1-6.

Oswald, A., Ransom, J.K., Kroschel J., Sauerborn, J. (2002). Intercropping controls Striga in maize based farming systems. Crop Protection, 21, 367374. doi:10.1016/S0261-2194(01)00104-1

Qiao, H., Liu, X., Li W., Huang, W., Li, C., Li, Z. (2006). Effect of deep straw mulching on soil water and salt movement and wheat growth. Chinese Journal of Soil Science, 37, (5), 885-889.

Randle, W.M. (2000). Increasing nitrogen concentration in hydroponic solution affects onion flavor and bulb quality. Journal of American Society of Horticultural Science, 125, 254-259.

Rasheed, M., Hussain, A., Mahmood, T. (2003). Growth analysis of hybrid maize as influenced by planting techniques and nutrient management. International Journal of Agriculture and Biology, 5, 169-171.

Rasheed, M., Mahmood, T., Nazir, M.S., Bhutta, W.A., Ghaffar, A. (2004). Nutrient efficiency and economics of hybrid maize under different planting methods and nutrient levels. International Journal of Agriculture and Biology, 6, 922-925.

Reddy, K.C., Reddy, K.M. (2005). Differential levels of vermicompost and nitrogen on growth and yield in onion (Allium cepa L.) - radish (Raphanus sativus L.) cropping system. Journal of Research ANGRAU, 33, (1), 11- 17. 
Rhoades, J.D. (1999). Use of saline drainage water for irrigation. In: Skaggs, R.W., van Schilfgaarde, J. (Eds.), Agricultural Drainage American Society of Agronomy (ASA)-Crop Science Society of America (CSSA)-Soil Science Society of America (SSSA). Madison, Wisconsin, USA, pp, 615-657.

Sayre, K. (2007). Conservation agriculture for irrigated agriculture in Asia. In: Lal, R., Suleimenov, M., Stewart, B.A., Hansen, D.O., Doraiswamy, P. (Eds.), Climate change and terrestrial carbon sequestration in central Asia. Taylor and Francis, The Netherlands, pp, 211-242. doi:10.1201/9780203932698.ch16

Shah, M.A., Manaf, A., Hussain, M., Farooq, S., Zafarul-Hye, M. (2013). Sulphur fertilization improves the sesame productivity and economic returns under rain fed conditions. International Journal of Agriculture and Biology, 15, 1301-1306.

Shaheen, A.H., Mona, M., Abdel, M., Aisha, A.M., Fatma, A.R. (2007). Natural and Chemical Phosphorus Fertilizers as affected Onion Plant growth, Bulb Yield and its some physical and Chemical Properties. Australian Journal of basic and applied science, INSI net publication. 1, (4), 519-524.

Siddique, M.F., Bakht, J. (2005). Effect of planting methods and nitrogen levels on the yield and yield components of maize. M.Sc (Hons) Thesis, Department of Agronomy, KPK Agric. Univ., Peshawar.

Singh, S., Yadav, P.K., Singh B. (2004). Effect of nitrogen and potassium on growth and yield of onion (Allium cepa L.) cv. Pusa Red. Haryana Journal Horticultural Sciences, 33, 308-309.
Songzhong, L., He H., Feng, G., Chen, Q. (2009). Effect of nitrogen and sulfur interaction on growth and pungency of different pseudostem types of Chinese spring onion (Allium fistulosum L.). Scientia Horticulturae, $\quad 121, \quad$ (1), $12-$ doi:10.1016/j.scienta.2009.01.019

Steel, R.G.D., Torrie, J.H., Dickey, D.A. (1997). Principles and Procedures of Statistic: A Biometrical Approach. 3rd edition, pp, 400- 428. Mc Graw Hill book Co. Inc. New York.

Subedi, D.K. (2001). Effect of irrigation on production and postharvest behaviour of onion (Allium cepa L.). Thesis, M. Sc. Institute of Agriculture and Animal Science, Rampur, Chitwan, Nepal, pp, 112.

Taiwo, L.B., Adediran, J.A., Akando, M.O., Banjoko, V.A., Oluwatosin, G.A. (2001). Influence of legume fallow on soil properties and yield of maize in South Western Nigeria. Journal of Agriculture in Tropics and Subtropics. 102, (2), 109-117.

Yadav, B.D., Khandelwal, R.B., Sharma, Y.K. (2005). Use of bio-fertilizer (Azospirillum) in onion. Indian Journal Horticulture, 62, (2), 168-70.

Yadav, R.L., Sen, N.L., Yadav, B.L. (2003). Response of onion to nitrogen and potassium fertilization under semi-arid condition. Indian Journal Horticulture, 60, (2), 176-178.

Yaso, I.A., Razzak, H.S.A., Wahb-Allah, M.A. (2007). Influence of biofertilizer and mineral nitrogen on onion growth, yield and quality under reclaimed calcareous soil condition. Journal of Agriculture and Environment Alexandria University Egypt, 6, (1), 245-26. 